\title{
Pengaruh Efektifitas Pembelajaran \\ Mata Kuliah Kewirausahaan terhadap \\ Minat Berwirausaha Mahasiswa Program Studi Perbankan Syariah IAIN \\ Bone
}

The Effectiveness Of Learning Entrepreneurship Effectiveness

On Student Interests Sharia Banking Study Program IAIN Bone

\author{
Zulkifli \\ Email: nalling_jnp@ymail.com \\ Dosen Ekonomi Mikro dan Makro Konvensional IAIN Bone \\ J1.HOS Cokroaminoto No.1, Tanete, Kabupaten Bone, Sulawesi Selatan \\ Raodatul Jannah \\ Email: raodhatuljannah91@gmail.com \\ Dosen Pengantar Akuntansi IAIN Bone \\ Jl.HOS Cokroaminoto No.1, Tanete, Kabupaten Bone, Sulawesi Selatan
}

\begin{abstract}
ABSTRAK
Tujuan penelitian ini yaitu untuk mengetahui bagaimana pengaruh efektifitas pembelajaran matakuliah kewirausahaan terhadap minat berwirausaha mahasiswa pada Program Studi Perbankan Syariah Jurusan Syariah dan Ekonomi Islam IAIN Bone. Teknik analisis data yang digunakan yaitu regresi linear sederhana. Hasil penelitian menunjukkan bahwa efektifitas pembelajaran matakuliah kewirausahaan berpengaruh positif dan signifikan terhadap minat berwirausaha mahasiswa pada Program Studi Perbankan Syariah Jurusan Syariah dan Ekonomi Islam IAIN Bone.
\end{abstract}

Kata Kunci: efektifitas; kewirausahaan; akuntansi; minat.

\begin{abstract}
The purpose of this study is to find out how the effectivity of the learning effectiveness of entrepreneurship courses on entrepreneurial interest in students in the Sharia Banking Department of Islamic Studies and IAIN Bone Islamic Economics Study Program. Data analysis techniques used were simple linear regression with the help of SPSS 20.00 for windows software. The results of the study showed that the effectiveness of entrepreneurship subject learning has a positive and significant effect on students' entrepreneurial interest in the Sharia Banking Department of Islamic Studies and IAIN Bone Islamic Economics.
\end{abstract}

Keywords: effectiveness; entrepreneurship; interest. 


\section{PENDAHULUAN}

Tidak dapat dipungkiri bahwa Provinsi Sulawesi Selatan menghadapi masalah keterbatasan kesempatan kerja bagi para lulusan perguruan tinggi, hal ini dapat dilihat dari semakin meningkatnya jumlah pengangguran intelektual. Berdasarkan data dari BPS Propinsi Sulawesi Selatan dapat dilihat bahwa pengangguran yang ada di Propinsi Sulawesi Selatan tahun 2016 yang terbesar adalah lulusan SLTA keatas termasuk didalamnya lulusan Sarjana (S1) yaitu sebanyak 135.428 orang

Tabel 1. Pengangguran Provinsi Sulawesi Selatan Tahun 2016

\begin{tabular}{|c|r|r|c|}
\hline \multirow{2}{*}{ Tingkat Pendidikan } & \multicolumn{3}{|c|}{ Pengangguran Tahun 2014 } \\
\cline { 2 - 4 } & Laki-Laki & Perempuan & Jumlah Penganggur \\
\hline SD ke bawah & 15.092 & 12.823 & 27.915 \\
\hline SLTP & 12.564 & 12.858 & 25.422 \\
\hline SLTA ke atas & 70.449 & 64.979 & 135.428 \\
\hline Jumlah & 98.105 & 90.660 & 188.765 \\
\hline
\end{tabular}

Sumber : BPS Propinsi Sulawesi Selatan

Dengan kondisi tersebut diatas bahwa lulusan serjana (S1) sebagaian besar menjadi pengangguran. Hal ini menunjukkan bahwa lulusan serjana (S1) sekarang tidak bisa mengandalkan ijazah saja untuk mendapatkan pekerjaan, tetapi harus mempunyai kemampuan dalam bidang lain salah satunya adalah wirausaha. Mahasiswa tidak boleh lagi berpikir setelah selesai kuliah mereka akan berkerja sebagai Pegawai Negeri Sipil (PNS) atau bekerja sebagai karyawan di perusahaan swasta atau BUMN karena perusahan-perusahan sekarang semakin semakin selektif dalam memilih karyawannya. Kondisi tersebut akan semakin diperburuk dengan situasi persaingan global (Masyarakat Ekonomi ASEAN/MEA) yang akan memperhadapkan lulusan perguruan tinggi Indonesia bersaing secara bebas dengan lulusan dari perguruan tinggi asing. Oleh karena itu, para sarjana lulusan perguruan tinggi perlu diarahkan dan didukung untuk tidak hanya berorientasi sebagai pencari kerja (job seeker) namun dapat dan siap menjadi pencipta pekerjaan (job creator) juga.

Salah satu solusi yang ditempuh untuk mengatasi pengangguran di Indonesia adalah dengan menciptakan wirausaha. Selain berpeluang menghasilkan pendapatan yang besar, berwirausaha juga mampu membantu pemerintah mengurangi jumlah pengangguran dengan menciptakan lapangan pekerjaan baru. Menciptakan seorang wirausaha dapat dimulai melalui pembelajaran kewirausahaan yang diajarkan di perguruan tinggi. 
Salah satu faktor pendorong pertumbuhan kewirausahaan disuatu negara terletak pada peran universitas melalui penyelenggaraan pendidikan kewirausahaan. Pihak universitas bertanggung jawab dalam mendidik dan memberikan kemampuan wirausaha kepada para lulusannya dan memberikan motivasi untuk berani memilih berwirausaha sebagai karir mereka. Pembelajaran kewirausahaan diharapkan mampu membangkitkan semangat berwirausaha, berdikari, berkarya dan mengembangkan perekonomian nasional.

Program Studi Perbankan Syariah di IAIN Bone dibuka dan mulai menerima mahasiswa tahun 2015. Program Studi Perbankan Syariah diharapkan berkontribusi menciptakan lulusan yang tidak hanya siap bekerja sebagai pegawai negeri sipil (PNS) atau Karyawan pada perusahaan swasta atau BUMN tetapi juga dapat menciptakan pekerjaan dengan bekal pembelajaran kewirausahaan selama mengikuti perkuliahan.

Berdasarkan latar belakang yang telah dipaparkan di atas, maka rumusan masalah dalam penelitian ini adalah :

1. Bagaimana efektifitas pembelajaran mata kuliah kewirausahaan mahasiswa Program Studi Perbankan Syariah di IAIN Bone?

2. Bagaimana minat berwirausaha mahasiswa Program Studi Perbankan Syariah di IAIN Bone ?

3. Bagaimana pengaruh efektifitas pembelajaran mata kuliah kewirausahaan terhadap minat berwirausaha mahasiswa Program Studi Perbankan Syariah di IAIN Bone?

\section{METODE PENELITIAN}

Penelitian ini dilaksanakan di Kampus IAIN Bone, Pemilihan lokasi ini sesuai dengan tujuan penelitian, yaitu peneliti ingin mengetahui pengaruh efektifitas pembelajaran matakuliah kewirausahaan terhadap minat berwirausaha mahasiswa Program Studi Perbankan Syariah IAIN Bone. Populasi adalah wilayah generalisasi yang terdiri atas: obyek/ subyek yang mempunyai kualitas dan karakteristik tertentu yang ditetapkan oleh peneliti untuk dipelajari dan kemudian ditarik kesimpulannya.. Populasi dalam penelitian ini adalah seluruh Mahasiswa program studi Perbankan Syariah di IAIN Bine yang berjumlah 510 Mahasiswa. Sampel adalah bagian dari jumlah dan karakteristik yang dimiliki oleh populasi tersebut. Bila populasi besar, dan peneliti tidak mungkin mempelajari semua yang ada pada populasi. Sampel adalah pengambilan sebagian objek untuk diselidiki yang akan mewakili populasi. Jika populasi kurang dari 100 orang, maka lebih baik diambil semua dalam penelitian, dan Selanjutnya jika populasinya besar, maka dapat diambil 10-15\%, 20-25\%, atau lebih. Dalam penelitian ini subyek atau responden yang dijadikan sampel mengambil $20 \%$ dari populasi, yaitu sebanyak 
102 Mahasiswa. Untuk mengetahui pengaruh efektifitas pembelajaran mata kuliah kewirausahaan terhadap minat berwirausahaan Mahasiswa Program Studi Perbankan Syariah di Perguruan Tinggi Keagamaan Islam Negeri (PTKIN) Sulawesi selatan, dilakukan uji regresi linear sederhana. Model penelitian yang digunakan dalam penelitian ini adalah :

$$
\mathrm{Y}=\alpha+\beta \mathrm{X}+\mathrm{e}
$$

\section{Keterangan :}

$$
\begin{aligned}
\mathrm{Y} & =\text { Minat berwirausaha Mahasiswa } \\
\mathrm{X} & =\text { Efektifitas Pembelajaran Mata kuiah Kewirausahaan } \\
\alpha & =\text { Intercept/Konstanta } \\
\beta & =\text { Parameter/koefisien regresi } \\
\mathrm{e} & =\text { Error terms }
\end{aligned}
$$

\section{HASIL DAN PEMBAHASAN}

\section{Analisis Deskriptif Variabel Penelitian}

\section{a. Efektifitas Pembelajaran Matakuliah Kewirausahaan}

Berdasarkan hasil penelitian yang dilakukan dengan membagikan angket kepada mahasiswa program studi perbankan syariah yang telah mengikuti matakuliah Kewirausahaan, diperoleh hasil yaitu tingkat Efektifitas pembelajaran mata kuliah Kewirausahaan, dikelompokan dalam lima kategori, yaitu: kategori tinggi, cukup, sedang, kurang dan rendah sebagai berikut:

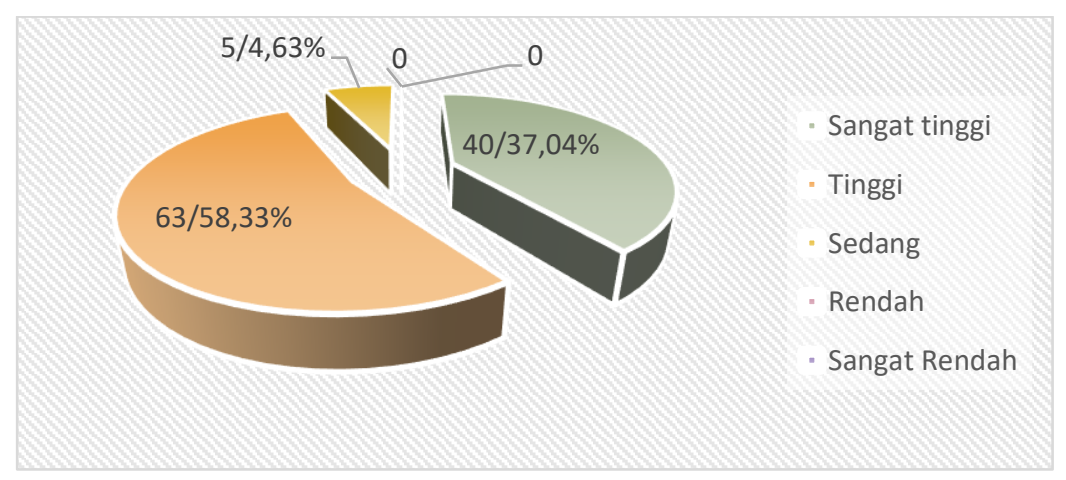

Sumber: Data hasil olah data 2018

Gambar 1. Efektifitas pembelajaran mata kuliah Kewirausahaan

Berdasarkan Gambar 1 diatas, diperoleh Efektifitas pembelajaran mata kuliah Kewirausahaan yaitu mahasiswa yang menjawab sangat tinggi yaitu sebanyak 40 mahasiswa atau 37,04 \% dari total responden, mahasiswa yang menjawab tinggi yaitu sebanyak 63 mahasiswa atau 58,33\% dari total responden, mahasiswa yang menjawab sedang yaitu 
sebanyak 5 siswa atau 4,63\% dari total responden, dan tidak ada mahasiswa yang menjawab rendah dan sangat rendah.

\section{b. Minat Berwirausaha Mahasiswa}

Berdasarkan hasil penelitian diperoleh IAIN Bone pada program studi perbankan syariah jurusan syariah dan ekonomi islam STAIN Watampone yaitu:

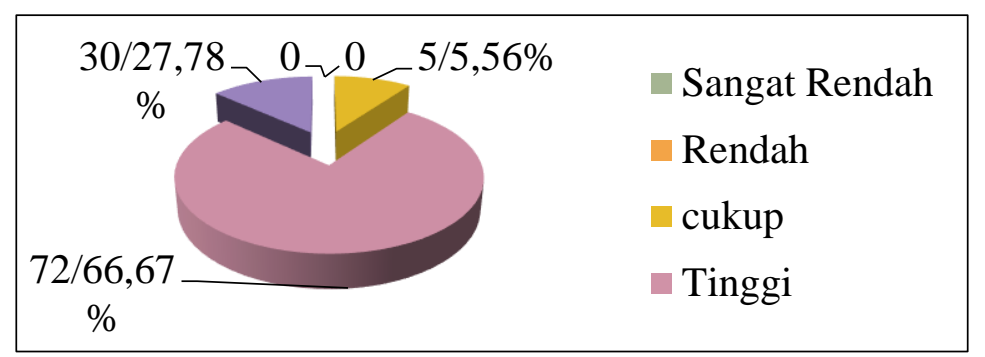

Sumber: Data hasil olah data 2018

Gambar 2 Minat Berwirausaha Mahasiswa

Berdasarkan Gambar 2 diatas, diperoleh Minat Berwirausaha Mahasiswa yaitu mahasiswa yang memiliki Minat Berwirausaha sangat tinggi yaitu sebanyak 30 mahasiswa atau $27,78 \%$ dari total responden, mahasiswa yang menjawab Tinggi yaitu sebanyak 72 mahasiswa atau 66,67\% dari total responden, mahasiswa yang menjawab sedang yaitu sebanyak 5 mahasiswa atau 5,56\% dari total responden, dan tidak ada mahasiswa dengan hasil belajar rendah dan sangat rendah,

\section{Pengaruh Efektifitas Pembelajaran Mata Kuliah Kewirausahaan Terhadap Minat Berwirausaha Mahasiswa IAIN Bone}

\section{a. Uji Normalitas}

Berdasarkan hasil olah data dapat dilihat bahwa titik-titik menyebar disekitar garis dan mengikuti garis diagonal, sehingga dapat disimpulkan bahwa data yang digunakan dalam penelitian ini adalah berditribusi normal sehingga dapat dilanjutkan pada analisis regresi.

\section{b. Uji Regresi Linear Sederhana}

Analisis regresi linear sederhana digunakan untuk mengetahui seberapa besar pengaruh variabel bebas terhadap varibel terikat. Analisis regresi linear sederhana dalam penelitian ini menggunakan program SPSS versi 20 yang dapat dilihat pada tabel 4.30 sebagai berikut: 
Tabel. 2 Hasil Olah Data Regresi Linear Sederhana

Coefficients $^{\mathrm{a}}$

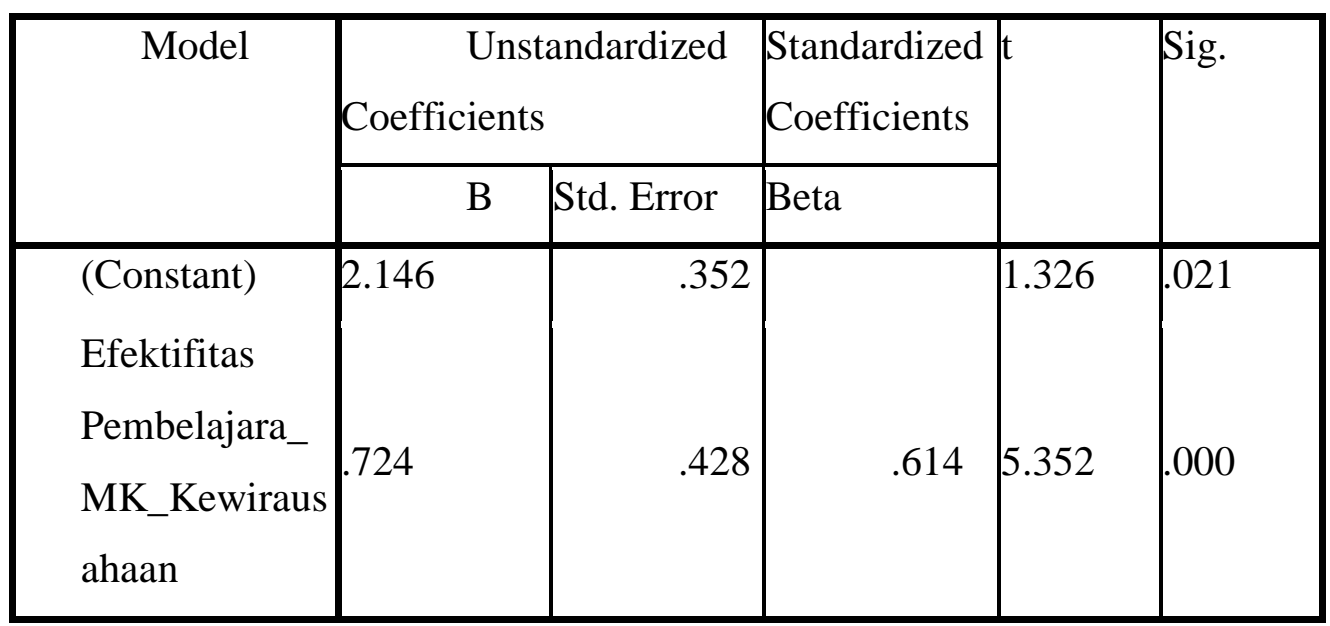

a. Dependent Variable: Minat_Berwirausaha

Berdasarkan hasil olah data tersebut persamaan dalam penelitian ini menjadi:

$Y=2,146+0,724+\varepsilon$

1. Nilai costanta sebesar 2,146

Jika tidak ada perubahan pada nilai variabel Efektifitas Pembelajaran Matakuliah Kewirausahaan, maka minat berwirausaha mahasiswa sebesar 2,146.

2. Nilai koefisien regresi kreativitas dosen sebesar 0,724 .

Nilai koefisien regresi efektifitas pembelajaran matakuliah kewirausahaan sebesar 0,724 menunjukkan bahwa jika efektifitas pembelajaran matakuliah kewirausahaan naik sebesar 1 maka minat berwirausaha mahasiswa akan naik sebesar 0,724. Dan sebaliknya efektifitas pembelajaran matakuliah kewirausahaan turun sebesar 1 maka minat berwirausaha mahasiswa akan turun sebesar 0,617. Sehingga dapat disimpulkan efektifitas pembelajaran matakuliah kewirausahaan berpengaruh positif terhadap minat berwirausaha mahasiswa, di Program studi perbankan syariah jurusan syariah dan ekonomi islam IAIN Bone.

3. Nilai signifikansi sebesar 0,000

Nilai signifikansi sebesar 0,000 menunjukkan bahwa variabel efektifitas pembelajaran matakuliah kewirausahaan berpengaruh signifikan terhadap minat berwirausaha mahasiswa di Program studi perbankan syariah jurusan syariah dan ekonomi islam IAIN Bone. 


\section{KESIMPULAN DAN SARAN}

Berdasarkan hasil penelitian maka dapat disimpulkan efektifitas pembelajaran matakuliah kewirausahaan berpengaruh positif dan signifikan terhadap minat berwirausaha mahasiswa, di Program studi perbankan syariah jurusan syariah dan ekonomi islam IAIN Bone.

\section{DAFTAR PUSTAKA}

Arikunto,(2012).penelitian suatu pendekatan praktek. Jakarta Rineka cipta.

Basrowi. (2011). Kewirausahaan untuk Perguruan Tinggi. Bogor: Ghalia Indonesia.

Darpujianto.(2014) Pengaruh pembelajaran kewirausahaan terhadap motivasi berwirausaha pada mahasiswa STIE dan STMIK 'ASIA' MALANG. Jurnal JIBEKA Volume 8 No 1 Februari 2014

E. Mulyasa. (2006). Menjadi Guru Profesional.Yogyakarta: Pustaka Belajar.

Gie, The Liang. (2006). Manajemen Administrasi Perkantoran Modern. Jakarta : Erlangga

Hendro.(2011).Dasar-Dasar Kewirausahaan. Jakarta: Erlangga

Kotler, Philip and Gary Armstrong. (2008). Prinsip-prinsip Pemasaran. Edisi. 12. Jilid 1. Jakarta: Erlangga.

Lestari R.B., wijaya T.(2012). pengaruh pendidikan kewirausahaan terhadap minat berwirausaha mahasiswa di STIE MDP, STMIK MDP, DAN STIE MUSI. Jurnal Ilmiah STIE MDP.

Lili S. \& Nani S. (2011) faktor yang berpengaruh terhadap niat Kewirausahaan. Jurnal fakultas ekonomi dan Bisnis Universitas Kristen Satya Wacana

Maman S. (2006). Pendidikan Wiraswasta. Jakarta: Sinar Grafika Offset.

Murwani. (2013). Faktor Penentu Minat Berwirausaha Dikalangan Mahasiswa Perguruan Tinggi Negri.Jurnal Studi Perguruan tinggi negri USU, UNI MED, IAIN

Sugiyono. (2016). Metode Penelitian Kuantitati, Kualitatif dan R\&D. Bandung: Alfabeta.

Sukardi (2013). Metodologi penelitian pendidikan kompetensi, dan prakteknya. Jakarta. Bumi Aksara

Thomas W Zimmerer, Norman M Scarborough,(2008) Kewirausahaan dan Manajemen. Usaha Kecil, Salemba empat

Tria Adetia (2017) pengaruh pembelajaran kewirausahaan, sikap, dan motivasi berwirausaha terhadap minat berwirausaha(studi pada anggota komunitas bisnis Indonesian Islamic Business Forumregional Lampung).Fakultas Ilmu Sosial Dan Ilmu Politik Universitas Lampung Bandar Lampung

Wiratmo, M. (2006). Pengantar Kewiraswastaan: Kerangka Dasar Memasuki Dunia Bisnis. Yogyakarta: BPFE. 